\title{
Luxación crónica recidivante. Tratamiento: osteotomía glenotemporal de Norman
}

\author{
Chronic recurring dislocation treatment: Norman glenotemporal osteotomy
}

\author{
L. Pingarrón Martín' , J.L.Cebrián Carretero², J. González Martín-Moro², J.M. López-Arcas', \\ M. Chamorro Pons 3, I. Navarro Cuellar', M. Burgueño García ${ }^{4}$
}

\begin{abstract}
Resumen: Introducción: Varios procedimientos quirúrgicos se han utilizado para limitar la apertura mandibular en pacientes con luxaciones recidivantes de la articulación temporomandibular (ATM). Éstas incluyen la inyección de agentes esclerosantes y el bloqueo mecánico mandibular. Otros métodos se basan en bloquear la traslación del cóndilo mandibular mediante la fractura del arco zigomático o mediante injerto óseo con aumento de la eminencia articular y la creación de un impedimento mecánico usando malla de vitalio o tornillos de acero inoxidable. Objetivo: Evaluar la experiencia de los autores en el tratamiento de las luxaciones recidivantes de mandíbula cuando se tratan ambos componentes: el óseo (eminencia) y el muscular (pterigoideo lateral). Material y métodos: 25 pacientes afectados de luxación recidivante (>3episodios/año) entre Enero 1997- Agosto 2008 con una edad media de 30 años; 21 de ellos son tratados de manera primaria y 4 por recidivas. Se realiza la técnica quirúrgica bajo anestesia general, incidiendo a lo largo del arco zigomático con una disección roma hasta exponer la pared anterior de la cápsula articular. Colocación de placa en "L" con fijación bicortical con tornillos. Resultados: Tras seguimiento radiológico y clínico tras la intervención (de 6 a 36 meses), se objetiva la ausencia de pérdidas de injerto, sin recidivas, remisión completa o parcial del dolor, buena apertura oral y ausencia de complicaciones importantes. Conclusión: La técnica descrita para restringir los movimientos de la ATM en casos de la dislocación crónica es relativamente simple, normalizando la función articular de forma inmediata sin necesitar tratamiento suplementario.
\end{abstract}

Palabras clave: Luxación recidivante; Osteotomía glenotemporal; Articulación temporomandibular; Miniplaca.

Recibido: 25.11 .2008

Aceptado: 11.05.2009

\begin{abstract}
Background. Various surgical procedures have been used to limit mandible opening in patients with recurrent dislocations of the temporo mandible joint (TMJ). These include intracapsular injection of sclerosing agents and tethering of the mandible. Other methods include obstruction of the condylar translation by downfracturing the zygomatic arch or by bone graft augmentation of the tuberculum and creating a mechanical impediment using Vitallium mesh or a stainless steel pin. Objective. To evaluate the author's experience in the treatment of recurrent dislocation of the mandible when both components, the osseous (eminence) and the muscular one (lateral pterigoideum), are treated. Material and methods. From January 1997 to August 2008, twenty-five patientes, 30 years old of averaged age, are affected by recurrent luxation ( $>3$ episodes/year). Twenty-one of them are treated primarily and four of them because of recurrences. The operative procedure is developed under general anesthesia, incising along the zygomatic arch using blunt dissection so that the front wall of the articular capsule can be exposed completely. An L-shaped plate is fixed bicortically with pins. Results. Radiological and clinical follow-up after the surgical treatment (6 to 36 months postoperatively) manifest the absence of lost graft, no recurrence, completed or partial pain remission, adequate mouth aperture and absence of important complications. Conclusion. The technique described for restricting TMJ movements in cases of chronic dislocation is relatively simple. The function of the TMJ was immediately normalized and no supplementary treatment was necessary.
\end{abstract}

Key words: Recurrent dislocation; Recurrent luxation; Glenotemporal osteotomy; Temporo mandible joint; Mini plate.

\footnotetext{
1 Médico Residente.

2 Médico Adjunto.

3 Jefe de Sección.

4 Jefe de Servicio.

Servicio de Cirugía Oral y Maxilofacial.

Hospital Universitario La Paz, Madrid. España
} 


\section{Introducción}

Se define como luxación articular la separación completa de las superficies articulares con la consiguiente situación del cóndilo en una posición anormal, generalmente anterior, sobrepasando la eminencia con incapacidad de volver a la fase articular.

La luxación recidivante de mandíbula es una patología poco frecuente que requiere un tratamiento definitivo. Los pacientes afectados peregrinan de uno a otro servicio de urgencias para solucionar episodios cada vez más frecuentes y en ocasiones más difíciles de tratar.

La luxación crónica de la articulación temporomandibular ocurre con frecuencia en pacientes con retraso mental (Sonnenberg y cols. 1985; Becking and Tuinzing, 1991) en aquellos que han sufrido daño cerebral ( Ohkawa y cols., 1996 ) y en varios síndromes (Gay Escoda, 1987).

El mecanismo fisiopatológico de estas lesiones no está claramente explicado, y una vez descartados los fármacos que pueden causar un síndrome extrapiramidal, otras causas frecuentes de luxación crónica del cóndilo son la parafunción y la luxación de los ligamentos articulares.

Las modalidades de tratamiento para esta patología difieren en su abordaje terapéutico y quirúrgico y son controvertidas.

Los diversos métodos de restricción mecánica de los movimientos mandibulares incluyen la fractura baja del arco zigomático, la implantación de mallas de vitalio o tornillos de acero.

Casi todos ellas centran su actuación en la eminencia articular, aumentándola o eliminándola. ${ }^{1}$

La osteotomía glenotemporal de Norman consiste en una osteotomía en tallo verde de la eminencia articular que es luxada inferiormente para aumentar su dimensión vertical al mismo tiempo que aumenta la inclinación de la eminencia impidiendo su luxación anterior. $^{2}$

Estas dos intervenciones tratan uno de los componentes causantes de la luxación, el óseo, pero no están exentas de recidivas ya que el componente muscular permanece inalterado. El músculo pterigoideo lateral, tiene una inserción móvil en el cuello de la mandíbula, en la cápsula y menisco de la ATM.

La cabeza esfenoidal se activa durante el cierre mandibular en la masticación, la deglución, el rechinamiento y apretamiento dental; mientras que la pterigoidea lo hace durante la apertura bucal y la protrusión mandibular.

En conjunto, el músculo tracciona hacia delante, del cóndilo mandibular, del disco articular y de la cápsula de la ATM; y actúa como antagonista del músculo temporal en la retracción mandibular.

El objetivo del presente artículo es evaluar la experiencia de los autores en el tratamiento de la luxación recidivante de mandíbula cuando se tratan ambos componentes, el óseo (eminencia) y el muscular (pterigoideo lateral).

\section{Material y método}

Entre Enero 1997- Agosto 2008, se operaron 25 pacientes afectados de luxación mandibular recidivante ( $>3$ episodios al año).

\section{Introduction}

Joint dislocation is defined by complete separation of the joint surfaces resulting in the abnormal position of the condyle, usually anterior, exceeding the eminence and unable to return to the joint phase.

Recurring mandible dislocation is a very common pathology that requires permanent treatment. Affected patients often travel from one emergency room to another to remedy these increasingly frequent and difficult to treat episodes.

Chronic dislocation of the temporo mandibular joint occurs frequently in patients with mental retardation (Sonnenberg et al., 1985; Becking and Tuinzing, 1991), those who have suffered brain damage (Ohkawa et al., 1996) and in those with various syndromes (Gay Escoda, 1987).

The physiopathalogical mechanism of these injuries is not clearly explained. Excluding pharmaceuticals that can cause extra pyramidal syndrome, parafunction and joint ligament dislocation are frequent causes of chronic condyle dislocation. Treatment methods for this pathology are very controversial and differ in their therapeutic and surgical approaches. These methods of restricting mandible movements include the lower fraction of the zygomatic arch and vitallium mesh or stainless steel pin implants.

Almost all of these approaches focus their attention on eliminating or augmenting joint eminence. ${ }^{1}$

Glenotemporal osteotomy of Norman consists of a green stick osteotomy in the joint eminence. It is inferiorly dislocated to augment its vertical dimension and at the same time augment the eminent incline preventing anterior dislocation. $^{2}$

These two interventions deal with one of dislocations' causing factors, the bone, but they are not free from recurrences because the muscular component remains unaltered.

The lateral pterygoid muscle has a movable insertion in the neck of the jaw, in the capsule and the TMJ.

The sphenoid head is activated during the closing of the mandible during chewing, swallowing and grinding and dental tightening. While the pterygoid is activated during mouth opening and mandible protrusion. As a whole the muscle drives forward, of the condyle mandible, joint disc, and the TMJ capsule. The muscle acts as an antagonist for the temporal muscle in its mandibular retraction.

The objective of this article is to discuss the authors' experience in treating recurring jaw dislocation when both the bone(eminence) and muscular(lateral pterygoid) components are treated.

\section{Material and Method}

Between August 1997 and August 200825 patients affected by recurring mandible dislocation were operated. 
Todos los pacientes requirieron en al menos una ocasión, asistencia hospitalaria para reducción de la luxación mediante maniobras manuales con o sin anestesia general o sedación.

Para evaluar el estado de la articulación en el preoperatorio se utilizó la RM. En el postoperatorio la evaluación y el seguimiento se realizaron con $\mathrm{TC}$.

El rango de apertura bucal no pudo evaluarse como medida clínica preoperatorio debido a la sintomatología de dolor y la tendencia a la luxación de algunos pacientes en la apertura extrema.

De los 25 pacientes, en 21 pacientes se realizó tratamiento primario. En un paciente el tratamiento fue tras fracaso de cirugía de Norman (osteotomía glenotemporal en tallo verde) en el que se interpuso injerto autólogo de calota sin fijación con placas. En la TC a los 12 meses de la cirugía se observaba reabsorción del injerto con traslación anterior del cóndilo articular. En los tres pacientes restantes, el fracaso quirúrgico fue tras la técnica de Myrhaugh (eminectomía articular).

El rango de edad de los pacientes de la serie que se describe está entre los 17 y los 58 años, con una edad media de 30 años.

La distribución por sexo es de 19 mujeres y 6 hombres, con 3 casos de mujeres con afectación bilateral de la ATM.

En 23 casos la obtención del injerto óseo fue a partir de calota del propio paciente, utilizando en este caso la misma vía de abordaje quirúrgico accediendo así a la región temporo-parietal. Dado que el grosor del injerto obtenido no es excesivo, se trata de un injerto de espesor total, pese a lo cual no supone complicación neuroquirúrgica añadida. En uno de estos casos se completó el procedimiento con una meniscopexia y en otro paciente, dado el daño severo de la articulación se realizó meniscectomía con interposición de músculo temporal.

En un caso el injerto fue tomado de la creta ílíaca homolateral a la ATM intervenida. Para ello se formó un segundo equipo quirúrgico que trabajó simultáneamente para disminuir el tiempo operatorio.

En solamente un paciente, el injerto interpuesto no fue autoinjerto, recurriendo a la colocación de hidroxiapatita.

El seguimiento de los pacientes de la serie fue radiológico mediante TC postquirúrgico a los 6 meses y 12 meses (excepto en 2 pacientes del 2008 que no han cumplido los 12 meses posoperatorios).

La evaluación clínica se realiza al mes y en los sucesivos $3,6,12$, 24 y 36 meses.

\section{Técnica quirúrgica}

La técnica que se describe en este artículo se centra en la elevación del tubérculo articular. Esto restringe la excursión del cóndilo mandibular previniendo el deslizamiento y la carga anterior del tubérculo.

Bajo anestesia general con intubación nasotraqueal, se realiza incisión de Al-Kayat de 1,5 centímetros a lo largo del arco zigomático (con extensión a región temporal en el caso de obtener injerto de calota).

Por medio de una disección roma se llega hasta la fascia temporal profunda, momento en el que se identifica la raíz del arco
All of the patients had needed at least on one occasion, hospital care to treat dislocation. Manual maneuvers were used with or without local anesthetic or sedative.

Before operating RMN was used to evaluate the condition of the joint. For the post operative evaluation and follow up the evaluation was carried out with TC. The range of mouth opening could not be measured before operation because of the pain symptoms and the tendency in many patients to dislocate when opening the mouth wide.

21 of the 25 patients had primary treatment. One of the patient's surgeries was after a failed Norman (green stick glenotemporal osteotomy) surgery where the autologous implant was interjected but not fixed with plates. 12 months after surgery the TC reported implant reabsorbing and forward movement of the condyle joint. In the 3 remaining patients failed surgery followed a Myrhag technique (joint eminectomy) Patients ages ranged from 17 to 58 and the average age was 30.

There were 19 women and 6 men, 3 of the women had bilateral TMJ affectation.

In 23 of the cases the graft was obtained from the calvarium of the patient themselves using the same surgical approach ascending to the temporoparietal region. Given that the implant is not excessively thick, it's a matter of total thickness; in spite this no additional neurosurgical complications are expected. In one of these cases the procedure was carried out using a meniscopexy and in the other patient, given the severe pain joint pain the temporal muscle interposition was used to carry out meniscectomy.

In one case the graft was taken from the homo lateral iliac crest of the operated TMJ. For this a second team of surgeons worked simultaneously to minimize operation time.

In just one patient the inserted graft was not auto graft, resorting to the placement of the hydroxiapatite.

The radiological follow up was taken using post surgical TC 6 and 12 months after surgery (except in 2 patients in 2008 that had not yet reached the 12 month date)

After 1 month and the following 3, 6, 12, 24, and 36 month patients underwent clinical evaluation.

\section{Surgical technique}

The technique described in this article looks at the elevation of the tubercle joint. This restricts the mandible condyle journey prior to the gliding and anterior loading of the tubercle.

Under local anesthetic using nasotrachial tubation, a 1.5 centimeter Al-Kayat incision is made along the zygomatic arch (with, in the case of calvarium graft, an extension to the temporal region).

Using blunt dissection we arrive at the deep temporal fascia at which time the zygomatic arch is identified. At this time we continue in a flat subperiostic to protect the frontal branch of the facial nerve. It also exposes the cheek bone 
cigomático. En este momento se continúa en un plano subperióstico para proteger la rama frontal del nervio facial, y se expone el arco cigomártico hasta identificar la eminencia articular y pared anterior de la cápsula articular (Figs. 12), manteniendo la inserción de los tejidos blandos periarticulares en la porción inferior.

La siguiente fase consiste en liberar la inserción del músculo pterigoideo lateral a nivel capsular y a nivel del menisco articular.

Seguidamente se realiza la osteotomía oblicua en tallo verde separando el arco cigomático de la eminencia articular. Para ello se aconseja la sierra reciprocante o una fresa de fisura fina. La osteotomía en la eminencia articular debe medir al menos $15 \mathrm{~mm}$ de profundidad. Un osteotomo fino facilita en este momento la separación de la eminencia articular del arco cigomático, antes de la interposición del injerto. El periostio de la superficie interna debe ser preservado para evitar la reabsorción de la eminencia.

El injerto óseo se conforma y se interpone en el segmento de osteotomía (Figs. 3 y 4 ).

Para realizar la osteosíntesis se coloca una placa de titanio en "L" con dos agujeros en su brazo corto. El brazo largo es situado anterior a la porción articular de la eminencia como obstructor mientras que el brazo corto está fijado al arco zigomático bicorticalmente con dos tornillos (Figs. 5 y 6).

Para probar si la placa restringe los movimientos articulares con eficacia, la mandíbula se mueve rotando a partir del eje de bisagra, de modo que el cóndilo se desplace anteriormente.

Finalmente se fijan los tornillos por completo y se cierra la incisión.

\section{Resultados}

En la presente serie no hubo pérdidas del injerto interpuesto a nivel de la osteotomía de la eminencia articular, así como tampoco se tuvo ninguna complicación importante en cuanto a sangrado o exposición de la dura durante el procedimiento quirúrgico. Asimismo, el dolor documentado por los pacientes durante el postoperatorio inmediato fue

Figura 1.

Figure 1.

Figura 2.

Figure 2.

Figura 3.

Figure 3.
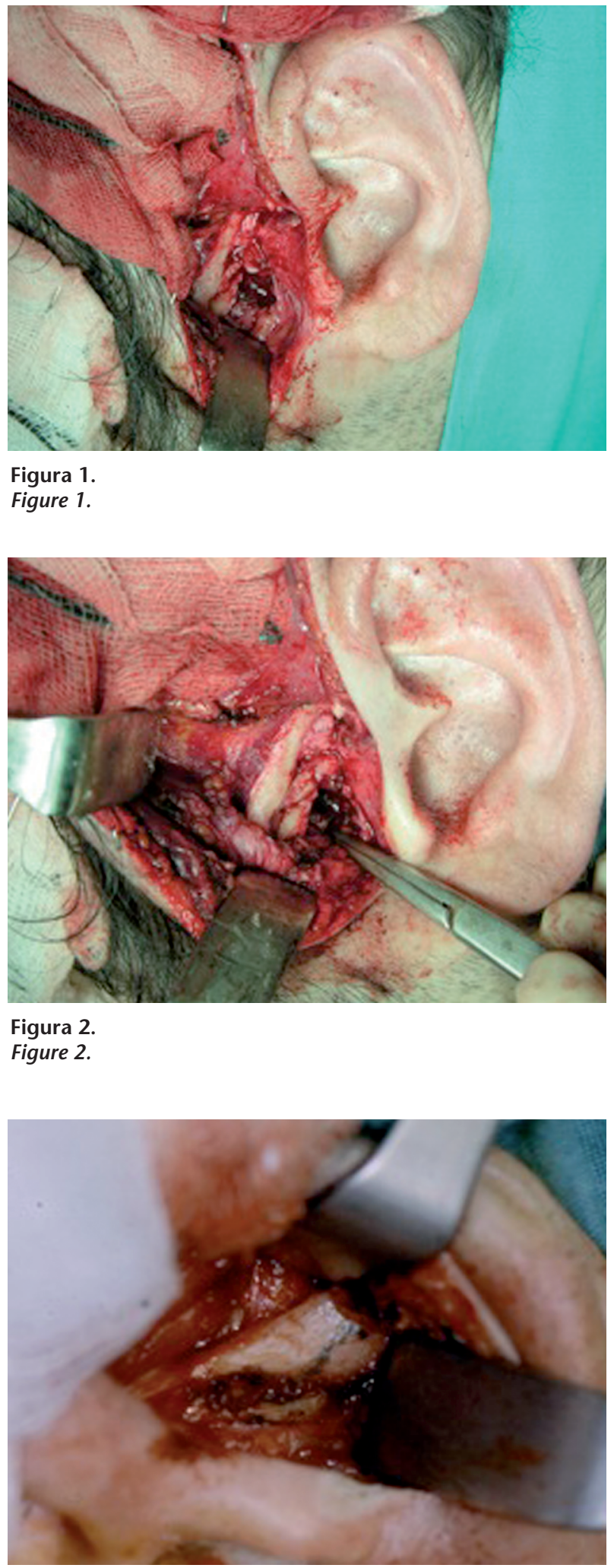
losses of grafts placed at the level of bone joint eminence. During surgery there were no serious complications in terms of bleeding or exposure of the "duramater". Pain directly fol- until the joint eminence and anterior wall of the joint capsule are identified (Figs. 1-2). The insertion of the soft periarticular tissue is kept in the inferior portion.

The next phase frees the pytergoid lateral muscle at a capsular and meniscus joint level.

Afterwards oblique green stick fracture is carried out, separating the cheek bone from the joint eminence. For this it is advisable to use a reciprocate saw or a fine fissure drill. Osteomy in joint eminence should be at least $15 \mathrm{~mm}$ deep. A fine osteotomy allows eminence and the zigomatic arch prior to the placement of the graft. Periostium of the internal surface should be preserved to avoid reabsorbing of the eminence.

The bone graft adapts and interjects in the osteotomy segment (Fig. 3) (design 1) To carry out the bone synthesis, a titanium plate, in shape of an "L", with two holes on the short arm is placed. The long arm is situated in front of the joint eminence to as an obstructer while the short arm is bicortically fixed to the zygomatic arch with two pins (Figs. 4-5).

To test if the plate efficiently restricts joint movements the mandible rotates from the axis of the hinge in a way that the condyle is displaces previously.

Finally the pins are completely tightened and the incision is closed.

\section{Results}

In this series there were no
level of bone joint eminence.
serious complications in terms
"duramater". Pain directly folfor the separation of the joint 
de intensidad leve-moderada con un buen manejo mediante analgesia convencional. Durante el primer mes postintervención, los pacienes mostraron una limitación a la apertura oral de $20-25 \mathrm{~mm}$, con resolución completa en la revisión clínica a los 3 meses.

A largo del seguimiento clínico, ningún paciente sufrió un nuevo episodio de luxación articular, con una buena apertura oral en todos ellos.

El dolor a largo plazo remitió por completo en 23 pacientes con una disminución considerable aunque no absoluto en los 2 pacientes restantes. La fisioterapia articular activa comenzó a partir del décimo día postoperatorio.

\section{Discusión}

Los síndromes de laxitud ligamentosa y de hipermovilidad articular están considerados por Kirk y cols. (1967), Jesse y cols. (1980) and Finterbush and Pogrund (1982) como una enfermedad inherente caracterizada por la hipermovilidad generalizada de todas las articulaciones. Bates y cols. (1984) encontraron una fuerte relación entre la laxitud de la ATM y la de la muñeca y el codo en mujeres.

La tendencia es pensar en una etiología multifactorial, en la que junto a disarmonías de la musculatura esquelética masticatoria se suma el hecho anatómico de una eminencia articular del temporal poco desarrollada.

Se han ideado múltiples intervenciones para el tratamiento definitivo de la luxación. Entre las diversas técnicas descritas están las actualmente abandonadas inyecciones intracapsulares de soluciones esclerosantes de iodo, alcohol, y psiliato sódico (Mc Kelvey, 1950), la nueva introducción en escleroterapia de inyección intraarticular y periarticular de sangre autóloga, 3,4 el bloqueo mecánico de los movimientos mandibulares mediante la fractura baja del arco zigomático o usando injertos óseos (Dingman y cols., 1975; Boudreau and Tideman, 1976), la restricción de la traslación del cóndilo por medio del implante de mallas de vitalio o tornillos de acero (Findlay, 1964; Howe y cols., 1978) y la eminectomía (Myrhaugh, 1951). ${ }^{5}$

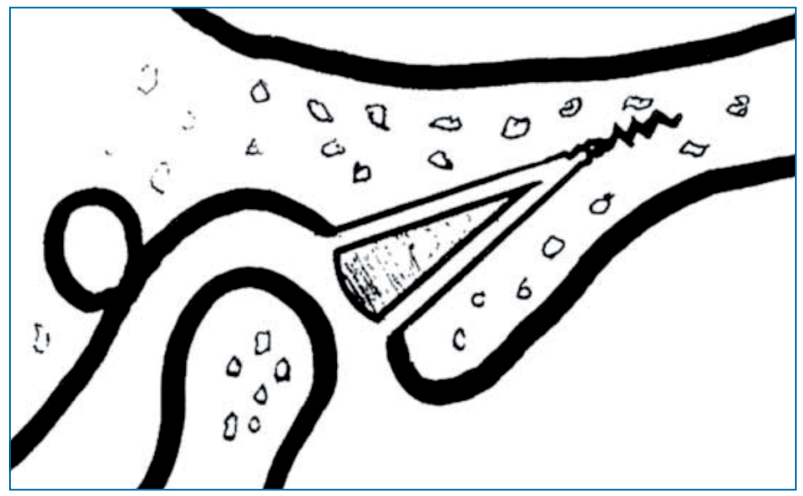

Figura 4. Ilustración esquemática de la dirección de la osteotomía oblicua en tallo verde y el lugar de colocación del injerto óseo9.

Figure 4.Schematic view of the direction of the green stick oblique osteotomy and the place for positioning the bony graft.

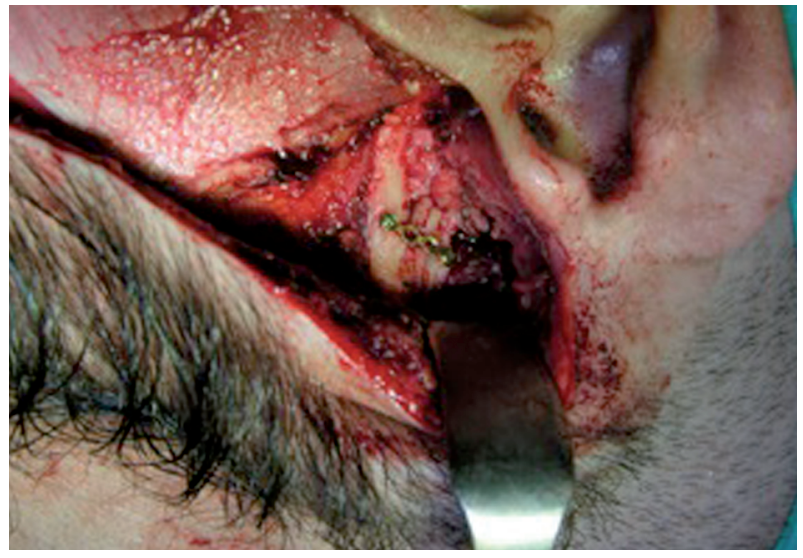

Figura 5.

Figure 5.

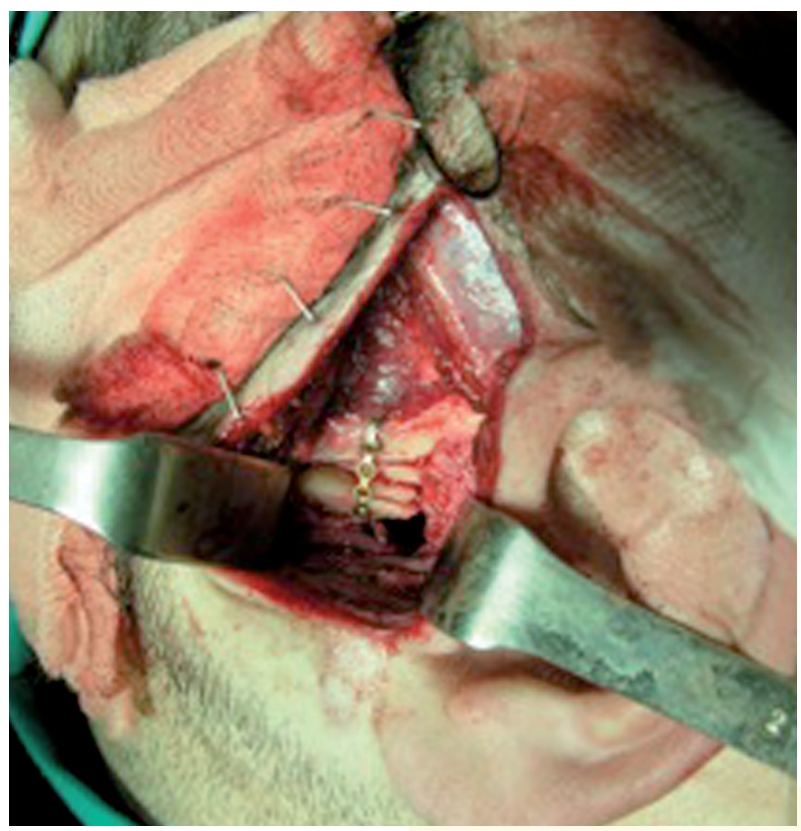

Figura 6.

Figure 6. lowing surgery was reported as light-moderate with a good handling of conventional intervening analgesia. During the first month after surgery the patients had mouth opening limitation of 20-25 mm. This situation had completely resolved itself at the 3 month clinical check-up. Through out the clinical follow up none of the patients had another dislocation and all of them had good oral openings.

The pain completely went away in 23 patients. The other 2 patients still had some pain but it was considerably less. Physical therapy of the joint started on the tenth day after surgery.

\section{Discussion}

Hyper mobility of the joint and lax ligament syndromes are considered inherent diseases characterized by generalized hyper mobility in all joints.(Kirk et al.1967, Jesse et al. 1980, and Finterbush and Pogrund 1982). Bates et al 1984 found a strong relationship in women between the looseness of the TMJ and the looseness of the wrist and elbow.

There is a tendency to think of a multifactorial etiology, in which there are inconsistencies in the skeletal chewing muscles in addition to the anatomical fact that the joint eminence of the temporal muscle is underdeveloped.

Multiple interventions have been devised to permanently treat dislocation. Among these diverse techniques are the recently abandoned intracapsular injections of sclerosing iodine, alcohol 
Varios casos han sido publicados utilizando la técnica de miniplacas. $^{6}$

Mientras Buckley and Terry (1988) manejaban la luxación crónica por medio del anclaje de una placa en el arco zigomático para limitar la traslación del cóndilo mandibular, Puelacher and Waldhart (1993) utilizaban miniplacas para alargar el tubérculo articular restringiendo el exceso de movimiento del cóndilo hacia delante. A través del uso de placas de osteosíntesis para elevar el tubérculo articular se restringieron los movimientos del cóndilo.

La osteotomía glenotemporal con interposición de injerto óseo no sólo incrementa la altura de la eminencia articular, sino que incrementa también su anchura evitando con ello la luxación del cóndilo. La intervención se realiza de forma extracapsular en todas sus fases.

Karabouta, ${ }^{7}$ documentó buenos resultados con la utilización de hidroxiapatita como material biocompatible interpuesto en el fragmento de osteotomía, a pesar de que hueso del propio paciente puede utilizarse como material de injerto. Este hueso autólogo puede obtenerse, en el mismo tiempo quirúrgico, de cresta iliaca, zona donante con suficiente cantidad de hueso y buena capacidad osteoconductiva, pero las desventaja de este tipo de injerto es que tiende a la reabsorción y se añade el problema de la morbilidad de la zona donante con molestias temporales a la deambulación. ${ }^{8}$

La tendencia actual es la obtención de injerto de calota de la región temporoparietal, con la principal ventaja de obtener hueso donante a partir de la misma incisión preauricular ampliada. ${ }^{9} \mathrm{~A}$ pesar del hecho de ser un injerto óseo generalmente fino (zona de calota monocortical), se pueden obtener ilimitadas cantidades de injerto sin morbilidad añadida siempre que la técnica quirúrgica sea cuidadosa.

A pesar de que en este tipo de intervenciones podemos encontrarnos con una serie de complicaciones potenciales de notable importancia como la parálisis facial por daño de la rama zigomática a nivel de la incisión preauricular, hemorragia importante fundamentalmente por daño de la arteria meníngea media y auricular anterior, infección del scalp, seroma, fractura del arco, daño del conducto auditivo externo y complicaciones en la zona donante del injerto en el caso de obtener el injerto de calota (fractura de la tabla interna y exposición de dura) no han sido documentadas en ninguna de las series publicadas en la literatura de los últimos años. $8,10-11$

El hueso receptor posee las mismas características que el injerto autólogo, por lo que la tendencia a la reabsorción es mucho menor.

La serie publicada por Medra y cols. ${ }^{8}$ muestra resultados igualmente favorables tanto si la osteosíntesis se efectúa con alambres o con placas, sin embargo, algunos autores no están de acuerdo con la introducción de materiales extraños periarticularmente, tales como miniplacas o tornillos, y apoyan el uso de alambres en la osteosíntesis para evitar problemas de infección, pérdida de tornillos o cuerpos extraños intraarticulares. ${ }^{12}$

Costas López y cols. ${ }^{1}$ afirman que no siempre es necesario el empleo de osteosíntesis dada la tendencia fisiológica a la obliteración, del espacio dejado en la osteotomía, siempre que el periostio de la parte medial de la eminencia articular se preserve durante la intervención.

La evolución de la serie presentada por los autores muestra que las articulaciones funcionan con normalidad tras el primer mes postoperatorio, sin limitación a la función de apertura entre los 25 y los $35 \mathrm{~mm}$. Dato añadido es la satisfacción subjetiva añadida de los and sodium solutions (McKelvey, 1950); the new introduction of sclerotherapy of intraarticular and periartiuclar injections of autologous blood, 3,4 the mechanical block of mandible movements by means of lower fracture of the Zygomatic arch or use of bone grafts (Dingman et al., 1975; Boudreau and Tideman, 1976). Other techniques include condyle movement restriction by implanting mesh or steel pins (Findlay, 1964; Howe et al, 1978) and eminectomy (Myrhaugh, 1951). 5

Many cases that use mini plates have been published. ${ }^{6}$ Meanwhile Buckley and Terry (1988) managed chronic dislocation by anchoring a plate to the zygomatic arch to limit condyle mandible movement. Puelacher and Waldhart (1993) used mini plates to lengthen tubercule joint which restricts the excessive forward movement of the condyle. Through the use of synthetic bone plates to elevate the tubercule joint condyle movement is restricted.

Glenotemporal osteomy with bone graft placement not only increases the height of the joint eminence but it also increases its width which avoids condyle dislocation. At all phases placement is carried out in an extra capsular manner.

Karabouta ${ }^{7}$ reported good results using hydroxiapatite as the biocompatible material interjected in the bone fragment, in spite of the fact that bone from the same patient can be used as graft material. This autologous bone can be found in the iliac crest at the time of surgery. The donor site must have a sufficient amount of bone and good bone conductivity. However, the disadvantage f this kind of graft is that it tends to be reabsorbed and adds problems to the morbidity of the donor zone as well as temporary discomforts when walking. ${ }^{8}$

The current tendency is to obtain the graft from the calvarium in the temporoparietal region. The main advantage is that the bone is obtained from the same enlarged preauricular incision. ${ }^{9}$ Despite being a generally fine bone graft, unlimited quantities of bone graft can be obtained without added morbidity as long as the surgery is carried out carefully.

We can encounter a series of potential complications with this type of intervention. These complications include facial paralysis due to zygomatic nerve damage when making preauricular incision, bleeding due to damage to the middle meningeal artery and anterior auricular, scalp infection, seroma and arch fracture. Other complications include : damage to the external auditory canal y complications in the donor graft zone when obtaining the graft from the calvarium (fracture of the internal table and repositioning of the dura have not been documented in any of the series published in the literature in the past few years).8, 10-11

The receiving bone has the same characteristics as the autologous graft which decreases the chances of reabsorbing.

The series published by Medra et al, 8 provides the same favorable results whether bone synthesis was with wires or with plates. However, some of the authors do not agree with introducing strange materials, such as mini plates and pins. They do support the use of wires for bone synthesis to avoid 
pacientes con los resultados quirúrgicos, con ausencia de recurrencias de luxación crónica.

\section{Conclusiones}

La técnica descrita para restringir los movimientos de la ATM en los casos de dislocación crónica es relativamente simple.

Para evitar el aflojamiento de la placa debe ser fijada por dos o tres tornillos anclados bicorticalmente sobre el arco zigomático.

Es importante no centrar únicamente el tratamiento en el componente óseo, siendo de suma importancia para la estabilidad de los resultados a largo plazo, el tratamiento del componente muscular con desinseción del músculo pterigoideo lateral del menisco y la cápsula articular.

La función de la ATM fue normalizada inmediatamente sin necesitar tratamiento suplementario.

\section{Bibliografía}

1. Costas López A, Monje Gil J. Glenotemporal osteotomy as a definitive treatment for recurrent dislocation of the jaw. J Cranio-Maxillofac Surg 1996;24:178-83.

2. Norman JE. Recurrent dislocation of the temporomandibular joint. Glenotemporal osteotomy and a modified dowel graft. B. European Association for Maxillofacial Surgery, 7th Congress, 1984.

3. Pinto A, McVeigh KP, Bainton R. Short Communication: The use of autologous blood and adjunctive "face lift" bandage in the management of recurrent TMJ dislocation. Br J Oral Maxillofac Surg 2009.

4. Machon V, Abramowicz S, Paska J. Autologous Blood Injection for the Treatment of Chronic Recurrent Temporomandibular Joint Dislocation. Br J Oral MaxiIlofac Surg 2009;67:114-9.

5. Myrhaug $\mathrm{H}$. A new method of operation for habitual dislocation of the mandibule, review on former methods of treatment. Acta Odont Scand 1951;9:247-61.

6. Shibata T, Yamashita T. Treatment of habitual temporomandibular joint dislocation with miniplate eminoplasty: a report of nine cases. J Oral Rehab 2002;29: 890.

7. Karabouta I. Increasing the articular eminence by the use of blocks of porous coralline hydroxyl apatite for treatment of recurrent TMJ dislocation. / Craniomaxillofac Surg 1990;18:107-13.

8. Medra A, Mahrous A. Glenotemporal osteotomy and bone grafting in the management of chronic recurrent dislocation and hypermobility of the temporomandibular joint. Br J Oral Maxillofac Surg 2008;46:119-22.

9. Harsha BC, Turvey TA, Powers SK. Use of autogenous cranial bone graft in maxiIlofacial surgery: a preliminary report. J Oral Maxillofac Surg 1986;44:11-9.

10. Güven O. Management of chronic recurrent temporomandibular joint dislocations: A retrospective study. Br J Oral Maxillofac Surg 2009;37:24-29.

11. Kuttenberger JJ, Hardt N. Long-term results following miniplate eminoplasty for the treatment of recurrent dislocation and habitual luxation of the temporomandibular joint. Int J Oral Maxillofac Surg 2003;32:474-9.

12. Smith WP. Recurrent dislocation of the temporomandibular joint: a new combined augmentation procedure. Int J Oral Maxillofac Surg 1991;20:98-9. infection, pin loss or foreign intraarticular bodies. Costa Lopez et al.' agree that it isn't always necessary to use bone synthesis given the physiological tendency to obliteration, from the space left in the osteomy, provided that the periostium of the central area of the joint eminence is well preserved during intervention.

The evolution of the series that the authors present shows that articulated joints work normally after the first month post surgery. They show no oral opening limitation between 25 and $35 \mathrm{~mm}$. Extra information is the subjective satisfaction of patients with their surgeries and the absence of recurring dislocation.

\section{Conclusions}

The technique described to restrict the ATM movements in chronic dislocation cases is relatively simple.

In order to avoid the weakening of the plate it should be fixed with two or three pins that are bi cortically anchored into the zygomatic arch.

It is important to only concentrate on the treatment of the bone, it being of great importance to the stability of the long term results, the muscular component treatment with detachment of the pytergoid lateral muscle of the disc and the joint capsule. The function of the ATM was immediately standardized without the need for supplementary treatment. 